\title{
Ostracism as a Manifestation of Xenophobia
}

\section{Остракізм як прояв ксенофобії}

\section{Victoriia Nazarevych}

Ph.D. in Psychology, Assistant Professor, Department of Age and Pedagogical Psychology Rivne State University of Humanities, Rivne (Ukraine)

ORCID ID: https://orcid.org/0000-0002-0111-7070

E-mail: nazarevich.art@gmail.com

\section{Вікторія Назаревич}

Кандидат психологічних наук, доцент, доцент кафедри вікової та педагогічної психології, Рівненський державний гуманітарний університет, м. Рівне (Україна)

\section{ABSTRACT}

The aim of the article is to explore the features of the concept of social isolation as a manifestation of xenophobia, which, due to their own characterological identities, carry a greater threat to society than open aggression.

The author used the method of synthesis to make an attempt to analyze personality's emotional, cognitive and behavioral structures that had influence on characteristics of ostracization's processes. The cognitive form includes selfawareness, self-observation, self-imagination, introspection, self-criticism and other signs of the destructive image of "Me» in a situation of social isolation. The cognitive component is characterized by the presence of irrational personality's constructs, the emotional one - by the phenomena of well-being, pride, which are also affected by social exile or neglect as the most common forms of ostracization in the social field.

Address for correspondence, e-mail: kpnu_lab_ps@ukr.net Copyright: (C) Nazarevych Victoriia

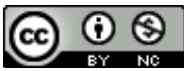

(c) Nazarevych Victoriia

DOI (article): https://doi.org/10.32626/2227-6246.2020-47.159-178 
DOI: https://doi.org/10.32626/2227-6246.2020-47 2020. ВипУск 47

In the article the author analyzed the psychological characteristics of individuals exposed to the phenomenon of social rejection. The main scientific views on the problem of ostracism, its role in the formation of xenophobic tendencies, emotional reactions and conditions that ostracize lives on, the role of psychological protective mechanisms, a sense of fear as the basic emotion of rejection of "alien" individuals are highlighted. The results of the research indicate the interdependence of socio-psychological environmental factors and the formation of trends of personal rejection.

The author made conclusions that are drawn in a system of considering the concept of ostracism as xenophobic manifestations, at a deep cognitiveemotional level, it affects the course of personality formation.

We see the further research of this problem in a more detailed study of the main criteria of xenophobic forms and ostracized reactions that arise when there is a threat of belonging, the alleged devaluation and denial of relations, as well as a study of the interdependence of open aggression and ostracized tendencies in the context of xenophobic manifestations of society.

Key words: ostracism, ostracizer, social exclusion, intolerance, xenophobia, emotional states, acceptance, protective mechanisms.

\section{Вступ}

Із поліпшенням соціального та морального клімату в світі ставлення до деяких суспільних явищ, які ще нещодавно домінували, істотно змінюється. Серед них і явище ксенофобії, проблема якої розглядається сьогодні психологами, соціологами й педагогами всього світу як одна з найбільш актуальних і глобальних у суспільстві.

Унаслідок швидкого розвитку процесів гуманізації людства, впровадження законів захисту й толерантності осіб, які входять до будь-яких соціальних меншин і сприймаються іншими як «чужі», виникає проблема прихованої форми неприйняття особистості - остракізм. Через власні характерологічні особливості він містить у собі більшу загрозу суспільству, ніж відкрита агресія: зокрема, як джерелом загрози демократії, правам і свободам індивіда цим явищем стурбовані всі міжнародні правозахисні організації. У про(C) Nazarevych Victoriia

DOI (article): https://doi.org/10.32626/2227-6246.2020-47.159-178 
грамних документах і звітах цих інститутів ставлення до нього визначається як винятково негативне.

Міжнародні конфлікти, які широко висвітлюються в засобах масової інформації, підвищують рівень негативізму, страху, агресивності, недовіри щодо представників іншості. Це у поєднанні з певними негативними стереотипами впливає на сприйняття «інших» особистістю. Розвитком цього явища стурбовані й науковці, адже індивід, перебуваючи в ситуації невідомого стану, несвідомо сприймає їі як негативну. Переживання подібних емоцій і проживання цього явища провокує невпевненість у завтрашньому дні, сприяє підвищенню тривоги, що знижує здатність індивіда критично оцінювати інформацію, надану суспільством і 3MI, paціонально підходити до вирішення соціальних проблем, що виникають.

Деякі науковці (G. C. Blackhart, B. C. Nelson, M. L. Knowles) наголошують: відторгнення особистості провокує емоціональні реакції, але не викликає безпосередніх страждань остракізованого (Blackhart, Nelson \& Knowles, 2009). Інші дослідники (M. J. Bernstein, S. G. Young, C. M. Brown, D. F. Sacco) вивчали адаптивні відповіді на соціальне відчуження й наголошували, що соціальне відторгнення покращує виявлення справжньої та підробленої посмішки (Bernstein, Young, Brown \& Sacco, 2008).

Ксенофобія узагальнено розглядається як прояв етнічної та політичної інтолерантності (Бромлей, 1971; Головаха, 1989; Водак, 2006; Дубов, 1992) - особливості формування у свідомості концепту «чужий».

Мета статті - теоретично розкрити проблематику остракізму як прояву ксенофобних тенденцій, висвітлити основні положення наукових публікацій із цієї теми.

\section{Завдання статті}

1. Розкрити поняття «ксенофобія» у системі наукових знань.

DOI (article): https://doi.org/10.32626/2227-6246.2020-47.159-178

(c) Nazarevych Victoriia 
DOI: https://doi.org/10.32626/2227-6246.2020-47 2020. випУск 47

2. Проаналізувати особливості й закономірності ксенофобних проявів особистості.

3. Описати взаємозалежність формування ксенофобних і остракізаторських проявів індивіда.

\section{Методи та методики дослідження}

Для реалізації мети дослідження було застосовано метод аналізу наукової літератури у таких сферах, як: поняття остракізму, особливості проходження стадій остракізації індивідом, форми явища, його проявів у контексті ксенофобних тенденцій в освітянському просторі.

Для дослідження остракізму як форми прояву ксенофобії в ситуації освітянських процесів здійснено синтез отриманих аналітичних даних.

\section{Результати та дискусії}

У сучасній науці існують різнобічні підходи як до розуміння феномену ксенофобії загалом, так і до специфіки ïï поширення. Деякі дослідники вважають, що сприймати ксенофобію потрібно як природне явище, що бере свій початок із тваринного світу та на рівні підсвідомості впливає на поведінку людини, коли вона натрапляє на суб'єкти, з якими не відчуває спорідненості за однією зі значущих для неї ознак. Учені стверджують, що феномен ксенофобії через цю інстинктивну природу не може бути викорінений: він спостерігається в соціумі упродовж усього існування людства (Солдатова, 2003: 16-19).

Термін «ксенофобія» походить від грец. xenos - чужий і phobos - страх, під ним розуміються різні прояви інтолерантності щодо груп, які сприймаються масовою свідомістю як «чужі»; страхи, спрямовані проти певних спільнот або груп (Кроз, 2005).

Вивчаючи сучасні напрями дослідження ксенофобії у підлітків, О. Маланцева (Маланцева, 2012: 14-25) зауважує, що стан соціального неприйняття проявляється в нега(C) Nazarevych Victoriia

DOI (article): https://doi.org/10.32626/2227-6246.2020-47.159-178 
тивних оцінних судженнях, антипатії з боку інших, в агресивних і насильницьких діях щодо узагальненого образу «чужого», незнайомого.

О. Муравйов виокремлює форми ксенофобії (Муравьев, 2004: 279-287):

1) інстинктивна - має біологічну, генетично закріплену природу, грунтується на пробудженні архаїчних інстинктів. Підтверджує таке спрямування й О. Леонтьєв, указуючи на безпідставність ставлення до «чужого» як до ворога. Він стверджує, що саме емоційний відгук на появу в свідомості категорії «чужого» актуалізує образ ворога, який накладається на його носія. У такий спосіб підкреслюється, що реальна поведінка чужинця практично не впливає на когніції, що вибудовуються у свідомості людини, яка їі сприймає, тобто негативне ставлення до «чужого» є безпідставним та упередженим, однак конструкти, що переважають у цей момент, не дають змоги це усвідомити (Кроз, 2005);

2) ідеологічна - виникає на основі інших соціальних фобій під впливом суспільних криз і несприятливих соціально-психологічних чинників, а також усвідомлення відмінностей іншої особи, які сприймаються як значущі та змушують зарахувати їі до аутгрупи. Своєю чергою, такі реакції провокують активацію стереотипів й установок, що викликають негативну емоційну реакцію, за якої загальнолюдські норми культури та моралі відходять на задній план, а особистість починає демонструвати неприйняття і ворожість до «чужого» (Гурина, 2016: 39-57) (рис. 1). Розкриваючи систему ксенофобії: інстинктивну й ідеологічну, це дає змогу передбачити наявні остракізовані ознаки, як один із критеріїв генезису ксенофобії як соціального явища.

Проведені дослідження М. Кроза й Н. Ратінової вказують, що неодмінною складовою когнітивного компонента соціальної ізоляції за критерієм «чужий» є: соціальні установки та стереотипи, упередження, оскільки за їх відсутності особистість мала б здатність до раціонального сприйняття

C) Nazarevych Victoriia

DOI (article): https://doi.org/10.32626/2227-6246.2020-47.159-178 
DOI: https://doi.org/10.32626/2227-6246.2020-47

іншої людини й оцінювала б їі перш за все як особистість, а не частину певної групи. Це дає підставу розглядати такі особистісні прояви (упередження, стереотипи, соціальні установки) як передпричини остракізму (Кроз, 2005).

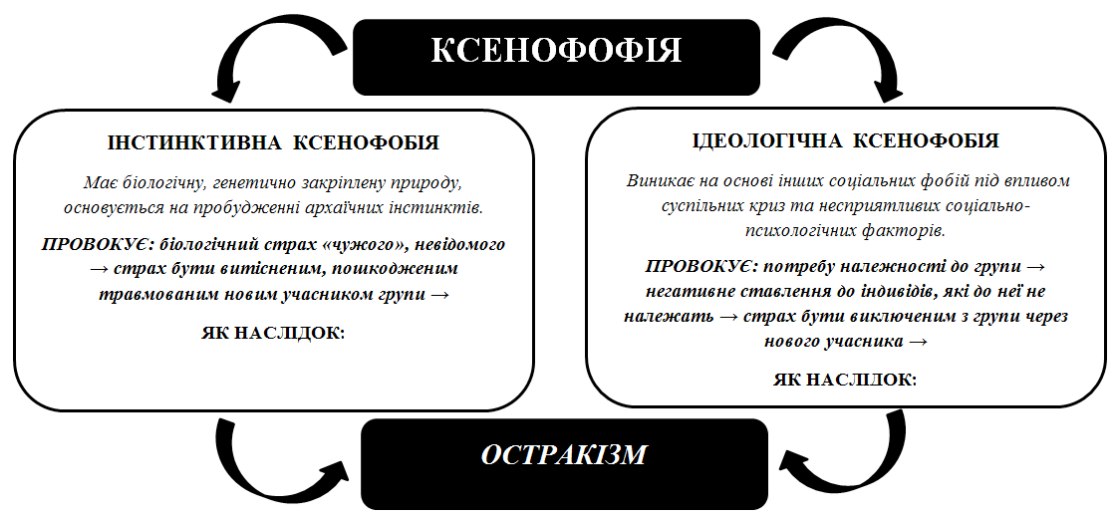

Puc. 1. Основні критерії генезису ксенофобії, їх зв'язок з остракізмом

Важливою для розуміння феномену ксенофобії є теорія культурного шоку Ф. Бока, у якій розглядається конфлікт двох культур, при цьому може матися на увазі як протистояння «своєї» та «чужої» культур, так і старої та нової. Загроза власним культурним цінностям породжуе в особистості спочатку страх і тривогу, а потім злість й агресію, прагнення захищати цінності, у які вона вірить. Відповідно, причиною ксенофобії можна вважати явище дефіцитарності (Leary, 2003).

Остракізм, зауважує Шефер (Шефер, 2004: 24-51), зараховують і до акту ігнорування та виключення окремих осіб, причиною чого можуть бути установки на суперництво, власну перевагу, завищення індивідуальної самооцінки й рівня домагань, авторитарність, підвищена тривожність як природний захисний механізм, що виникає на невідомі, «чужі» прояви.

(C) Nazarevych Victoriia

DOI (article): https://doi.org/10.32626/2227-6246.2020-47.159-178 
Головна теза, на яку ми спиратимемося в наших дослідженнях остракізму та його проявів, що це форма утримання власної ідентичності, де вигнання стає підсвідомим мотивом для самозбереження умовної цілісності від руйнівних ознак «іншості». Присутність невідомого провокує інстинктивні форми рефлексивного відображення напруження у деструктивних остракізованих формах. Психоемоційне напруження в остракізатора може проявлятися у когнітивній, емоційній і поведінковій формах.

Згідно із сучасними уявленнями, структуру остракізму як ксенофобного прояву становлять когнітивний, емоційний і поведінковий компоненти. До пізнавальної форми належать самовідчуття, самоспостереження, уявлення про себе, самоаналіз, самокритика й інші ознаки деструктивного образу «Я» в ситуації соціальної ізоляції (Горбачова, 2012). О. Горбачова наголошує, що у змісті когнітивного компонента превалюють ірраціональні конструкти, які, однак, приховані псевдораціональним обгрунтуванням, що дає змогу особистості підтримувати несуперечливий образ себе та навколишньої дійсності, захищає їі від усвідомлення деструктивності власних тенденцій, спрямованих на завдання психологічної чи фізичної шкоди іншій людині (ОрбанЛембрик, 2007: 22-26).

До емоційної форми відносимо самопочуття, самолюбство, гордість, скромність, почуття власної гідності й відповідальності, які також піддаються впливу соціального вигнання чи ігнорування як найпоширеніших форм остракізації в соціальному просторі.

До поведінкової форми зараховуємо самоконтроль, самовладання, стриманість, самодисциплінованість, яка в спостереженнях проявляється у формі невротичного самообмеження, безініціативності чи постійного бажання до захисту або боротьби (рис. 2). 


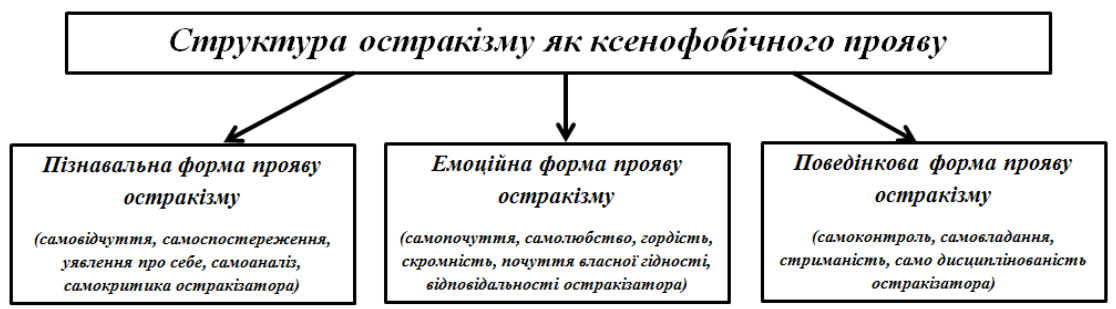

Puc. 2. Структура остракізму в контексті прояву ксенофобії

Упередження розглядається як негативна установка щодо певних груп осіб, що актуалізується в ситуації загрози власній групі, форма відображення та оцінки, яка характеризується негативним емоційним зарядом і відповідає таким формам поведінки, як уникнення спілкування або ухилення від контактів у певних сферах життєдіяльності. Г. Олпорт виокремлює історичні, економічні, соціокультурні, ситуаційні, психогенні, феноменологічні типи упереджень, стверджуючи, що всі вони здатні за певних умов породжувати прояви ворожості, що засвідчує актуалізацію остракізаторських тенденцій (Олпорт, 2002; Трофимова, 2009).

Розглядаючи стереотипи як частину когнітивної сфери особистості, варто наголосити, що в їх основі лежать уявлення, які вже потім набувають емоційного забарвлення. Це дозволяє нам розглядати стереотип саме як когніцію, що за актуалізації набуває того чи іншого емоційного полюса та зумовлює відповідні поведінкові акти (Борейчук, 2014: 33-39).

Ю. Платонов підкреслює: стереотипи не завжди є негативними й не у будь-якій ситуації провокують прояви остракізації. Так, за умов соціальної стабільності вони можуть функціонувати на рівні підсвідомості та не проявлятися в конкретних діях. У цьому випадку когніції щодо «чужого» залишаються незмінними, однак, за відсутності поштовху, не набувають емоційного забарвлення (Борейчук, 2014: 33-39).

(C) Nazarevych Victoriia

DOI (article): https://doi.org/10.32626/2227-6246.2020-47.159-178 
Виникнення негативної соціальної установки щодо «чужих» індивідів і груп, на думку більшості зарубіжних дослідників, зумовлено орієнтацією на соціальне домінування, що запускає механізм формування етноцентризму та зумовлює прояви дискримінації, оскільки власна соціальна чи етнічна група сприймається як така, що стоїть на вищому щаблі розвитку, а інші - як такі, що не заслуговують на прийняття та повагу (Горбачова, 2012).

Пояснюючи негативне, емоційно насичене ставлення до категорії «чужих», що є однією з ознак ксенофобії й остракізму, С. Носов пов'язує їх із суб'єктивним відчуттям загрози, небезпекою втратити свої ресурси, ідентичність, життєвий простір. Тож особистість раціоналізує власну поведінку, виправдовує вчинки, сприймає себе «борцем за справедливість», а «чужого» - як загрозу чи завойовника (Олпорт, 2002).

У характеристиці емоційної складової цього явища можна використати поняття «самодостатнього страху», що під впливом механізмів психологічного захисту переростає в агресію, яка може проявлятися у різних формах, залежно від установок і рівня культури особистості. В емоційній складовій переважають такі почуття, як страх, відраза, неприязнь, неприйняття (Гурина, 2016: 39-57).

На нашу думку, в основі остракізаторської поведінки лежить не лише страх як базова емоція, а й такі почуття та стани, як: неприязнь, нетерпимість, неприйняття, заперечення чужого, недовіра, незгода, роздратування, недружелюбність, підозрілість, ворожість, ненависть, агресія, гнів.

Презирство передбачає почуття власної переваги над іншою людиною, що не дає змоги особистості здійснити реальну оцінку об'єкта сприймання, а це, своєю чергою, породжує упереджене й стереотипне ставлення. Презирство вирізняється стійкістю та зумовлює стабільну негативну оцінку «чужого» суб’єкта (Кроз, 2005).

(C) Nazarevych Victoriia

DOI (article): https://doi.org/10.32626/2227-6246.2020-47.159-178 
Емоція огиди передбачає усвідомлення невідповідності об'єкта чи суб'єкта моральним або естетичним принципам i установкам людини. Оскільки у випадку прояву ксенофобії сприймання особистості є викривленим і зміненим під впливом установок і стереотипів, то «чужий» викликає відразу автоматично, за відсутності намагання його зрозуміти та краще пізнати (Трофимова, 2009). Як зазначає К. Ізард, відчуття огиди найтісніше пов'язане з емоцією гніву. В ксенофоба відчуття огиди щодо «інших» виявляється у вимогах сегрегації таких осіб, їх ізоляції (Гурина, 2016: 39-57).

Базовою емоцією, що міститься в основі виникнення ксенофобних реакцій, є страх. Фізіологічною основою страху є складна рефлекторна реакція організму на внутрішні й зовнішні подразники, які спричиняють уявну або реальну небезпеку.

Переживання ірраціонального страху впливає на перебіг у нервових клітинах і корі головного мозку основних нервових процесів - збудження й гальмування, їх динаміку та співвідношення. Нервові клітини переходять у так званий фазовий стан, унаслідок чого їх реакція на подразники перестає бути адекватною (Борейчук, 2014: 33-39). Утрачається здатність особистості до об'єктивної оцінки ситуації, образ «чужого», що набуває характеристик «ворога», домінує у свідомості, оскільки сприймається як джерело небезпеки, що і породжує остракізаторські тенденції.

Емоційна реакція на «іншого» може проявлятися у формі побоювання як частково усвідомленого страху. Контакти з незнайомими людьми підвищують негативну емоційну активацію, оскільки в особистості немає досвіду такої взаємодії, і вона не знає, чого від неї можна очікувати (Шефер, 2004: 24-51).

Е. Фромм наголошував на тому, що все чуже, викликаючи в особистості певну зацікавленість, водночас породжує страх, підозру та заперечення, оскільки вимагає використання нових патернів поведінки. У цьому випадку (C) Nazarevych Victoriia

DOI (article): https://doi.org/10.32626/2227-6246.2020-47.159-178 
«чужий» набуває негативного емоційного відгуку, оскільки його специфічні особливості не вкладаються у звичну для індивіда систему оцінки (Орбан-Лембрик, 2007: 22-26).

Специфіка емоційного реагування зумовлюе ступінь прояву цього явища. Підкреслюємо також різну роль страху в контексті зіткнення 3 «чужим»: він може відігравати мобілізуючу, регулюючу, мнемонічну, орієнтуючу, креативну функції. Однак в іншому випадку має деструктивну, демобілізуючу, дезорганізуючу, дезорієнтуючу функції, що слугує джерелом негативного реагування на особистість та їі соціальну ізоляцію (Солдатова, 2003: 16-19).

Отже, особистість уникає взаємодії з представниками «іншості», позаяк захищає себе від усвідомлення їх переваги, що призведе до руйнування звичного світосприйняття та зниження власної самооцінки.

У вивченні остракізму як прояву ідеологічної ксенофобії варто звернути увагу на те, що у процесі виникнення ксенофобних тенденцій разом із соціально-психологічними - сугестивними механізмами (навіювання, зараження, міфологізація, внутрішньогруповий фаворитизм, ефект дегуманізації жертви), значну роль відіграють механізми психологічного захисту, до яких належать: ідентифікація, проекція й інтелектуалізація (Williams, 2001).

Механізм ідентифікації набуває особливої значущості при остракізації, оскільки саме на його основі відбувається розділення на категорії «свій» $\mathrm{i}$ «ужий». Ідентифікація зумовлює зарахування себе до певної групи на основі усвідомлення спільних ознак з їі членами. Натомість механізм категоризації сприяє утворенню у свідомості групи «чужих», із якими в особистості мало спільного. При цьому такий розподіл соціуму відбувається на основі запрограмованої моделі, готових схем, а не у процесі безпосереднього пізнання навколишньої дійсності (Проник, 2012: 212-215).

Механізм інтелектуалізації, порівняно з проекцією, є більш зрілим і запускає процес псевдопояснення мотивів де(C) Nazarevych Victoriia DOI (article): https://doi.org/10.32626/2227-6246.2020-47.159-178 
DOI: https://doi.org/10.32626/2227-6246.2020-47

2020. випуск 47

структивної поведінки, упереджень і стереотипів із метою виправдання як безпосередньо себе, так і групи, до якої особистість належить (Скулкина, 2015: 58-60) (рис. 3).

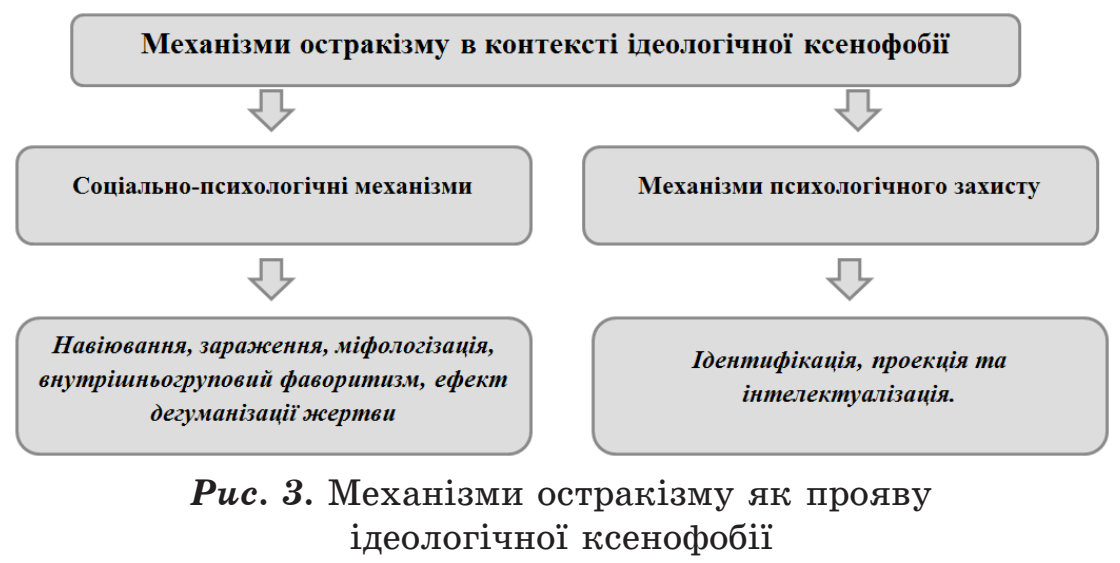

Виникнення образу «чужого» пояснюється в контексті теорії категоризації Г. Теджвела і Т. Тернера, де обгрунтовується процес соціальної адаптації крізь призму обов'язкового поділу соціуму на категорії та зарахування себе до певної групи. У зв'язку з цим усе «чуже» зараховується до аутгруп, а «своє» - до інгруп (Шютц, 2003). Формування образу «чужого» пов'язано з розподілом соціуму на категоpiï «ми - вони», що склалося історично, оскільки закриті «ми-групи» мали кращі умови для виживання в первісному суспільстві, тоді як «вони-групи» викликали насторожене чи вороже ставлення, тому що сприймались як загроза. Зарахування особистості до однієї з цих категорій відбувається завдяки соціальній ідентичності, що включає систему уявлень, знань, мотивів, емоцій, поведінкових схем i неусвідомлених утворень. У процесі усвідомлення своєї ідентичності особистість приймає певний спосіб життя, властивий «ми-групі», підкоряється їі нормам і цінностям. У формуванні ідентичності відбувається взаємодія процесів (C) Nazarevych Victoriia

DOI (article): https://doi.org/10.32626/2227-6246.2020-47.159-178 http://journals.uran.ua/index.php/2227-6246 
ототожнення та відділення, що і забезпечує розподіл навколишнього світу на категорії «своє» $\mathrm{i}$ «чуже». Збільшенню дистанції між категоріями «ми» i «вони» сприяють значні культурно-психологічні відмінності, оцінка загрози від аутгруп, безперспективність взаємодії з ними (відсутність вигоди) (Орбан-Лембрик, 2007: 22-26).

\section{Висновки}

Теоретичний аналіз аспектів остракізму як прояву ксенофобії дав змогу обгрунтувати поняття ксенофобії, яке використовується для позначення страху до чужих, нетерпимості до них, що є проявом інтолерантності стосовно груп, які сприймаються масовою свідомістю як «чужі» .

Аналізуючи теоретичні відомості, які висвітлюють порушену проблему, з'ясовано, що існує два основних джерела ксенофобних настроїв:

- інстинктивна ксенофобія - має біологічну, генетично закріплену природу, базується на пробудженні архаїчних інстинктів і включає в себе соціальні установки, стереотипи й упередження. Крім цього, вона спричинена суб'єктивним відчуттям загрози особистості, тобто небезпеки втратити свої ресурси, ідентичність, життєвий простір, і вказує на страх як на базову емоцію індивіда при зіткненні з незнайомим, а також спектр інших станів, таких як: відраза, неприязнь, неприйняття тощо;

- ідеологічна ксенофобія - виникає на основі інших соціальних фобій під впливом суспільних криз і несприятливих соціально-психологічних чинників. Такі чинники провокують активацію стереотипів та установок, що викликають негативну емоційну реакцію, за якої загальнолюдські норми культури й моралі відходять на задній план, а особистість починає демонструвати неприйняття та ворожість до «чужого».

Виявлено, що ксенофобія в освітніх закладах має такі форми прояву: негативні оцінні судження, антипатії з боку

(c) Nazarevych Victoriia

DOI (article): https://doi.org/10.32626/2227-6246.2020-47.159-178 
інших, агресивні та насильницькі дії щодо узагальненого образу «чужого», незнайомого.

Здійснено аналіз теоретичних знань про перебіг процесів формування остракізму і ксенофобії, виявлено, що їх зараховують до акту ігнорування та виключення окремих осіб, причиною чого можуть бути установки на суперництво, власну перевагу, підвищена тривожність як природний захисний механізм, що виникає на невідомі, «чужі» прояви.

На основі узагальнення стану розроблення проблеми показано, що формування остракізаторських тенденцій, як i ксенофобічних нахилів, зумовлено процесом соціальної адаптації: враховуючи обов'язковість суспільного поділу на групи, зарахування особистості до однієї з цих категорій відбувається завдяки соціальній ідентичності, що включає систему уявлень, знань, мотивів, емоцій, поведінкових схем і неусвідомлених утворень.

Подальший розгляд цієї проблеми вбачаємо в більш розгорнутому вивченні основних критеріїв ксенофобних форм та остракізованих реакцій, що виникають при загрозі приналежності, передбачуваної девальвації та відмови у взаєминах, а також у дослідженні взаємозалежності кількості відкритої агресії й остракізованих тенденцій у контексті ксенофобних проявів суспільства.

\section{Література}

Борейчук I. О. Образ «чужого» в психічних структурах «Я». Науковий вісник Чернівецького національного університету: зб. наук. праць. 2014. Вип. 700. С. 33-39.

Бромлей Ю. К характеристике понятия «этнос». Расы и народы. 1971. № 1. C. $26-27$.

Водак Р. Взаимосвязь «дискурс - общество»: когнитивный подход к критическому дискурс-анализу. Совреленная политическая лингвистика. Екатеринбург, 2006. 235 с.

Головаха Е. И. Психология человеческого взаимопонимания. Киев : Политиздат, 1989. $211 \mathrm{c.}$

(C) Nazarevych Victoriia

DOI (article): https://doi.org/10.32626/2227-6246.2020-47.159-178 
Горбачова О. В. Протидія проявам ксенофобії органами внутрішніх справ України: соціально-технологічний аспект: автореф. дис. ... канд. соціол. наук. Харків : Нац. ун-т внутр. справ, 2012. 20 с.

Гурина О. Д. Ксенофобские установки и личностные особенности подростков с девиантным поведением. Психология и право. 2016. № 1. С. 39-57.

Дубов И. Г. Восприятие личности политического деятеля. Психологический журнал. 1992. № 6. С. 24-26.

Кроз М. В. Соціально-психологічні та правові аспекти ксенофобії. Москва, 2005. 40 с.

Маланцева О. Д. Современные направления исследования ксенофобии среди подростков. Совреленная зарубежная психология. 2012. № 3. С. $14-25$.

Муравьев А. Ксенофобия: от инстинкта к идее. Отечественные записки. 2004. № 4 (19). С. 279-287.

Олпорт Г. Основные положения психологии личности. Становление личности. Избранные труды. Москва : Смысл, 2002. 216 с.

Орбан-Лембрик Л. До питання про міжгрупові конфлікти й упередження. Соціальна психологія. Чернівці, 2007. № 3. С. 22-26.

Проник О. Ю. Система суб'єктів протидії ксенофобії. Право і сусnільство. 2012. № 1. С. 212-215.

Скулкина Е. Н. Индивидуально-психологические детерминанты формирования социальных установок ксенофобии у подростков. Психопедагогика в правоохранительных органах. 2015. № 60. С. 58-60.

Солдатова Г. У. Практическая психология толерантности, или как сделать так, чтобы зазвучали лучшие струны человеческой души. Век толерантности: научно-публицистический вестник. Москва, 2003. № 6. С. 16-19.

Трофимова Е. Л. Особенности потенциалов межэтнической конфликтности в юношеском возрасте и их коррекция: автореф. дис. ... канд. психол. наук. Москва : МГППУ, 2009. 25 с.

Шефер Б. Восприятие чужого как фактор возникновения амбивалентных чувств. Психология. Минск, 2004. № 1. С. 24-51.

Шютц А. Смысловая структура повседневного мира. Москва, 2003. $177 \mathrm{c}$.

Bernstein, M. J., Young, S. G., Brown, C. M., Sacco, D. F., \& Claypool, H. (2008). Adaptive responses to social exclusion: Social rejection improves detection of real and fake smiles. Psychological Science, 19, 981-983.

Blackhart, G. C., Nelson, B. C., Knowles, M. L., \& Baumeister, R. F. (2009). Rejection elicits emotional reactions but neither causes im-

(C) Nazarevych Victoriia

DOI (article): https://doi.org/10.32626/2227-6246.2020-47.159-178 
DOI: https://doi.org/10.32626/2227-6246.2020-47 2020. випУСК 47

mediate distress nor lowers self-esteem: A meta-analytic review of 192 studies on social exclusion. Personality and Social Psychology Review, 13, 269-309.

Leary, M. R., \& MacDonald, G. (2003). Individual differences in selfesteem: A review and theoretical integration. Handbook of self and identity. New York : Guilford Press. 418 p.

Williams, K. (2001). Ostracism: The Power of Silence. New York : Guilford Press.

\section{References}

Boreichuk, I. O. (2014). Obraz «chuzhoho» v psykhichnykh strukturakh «Ya» [The image of «alien» in the mental structures of «Me»]. Naukovyi visnyk Chernivetskoho natsionalnoho universytetu - Scientific Bulletin of Chernivtsi National University, 700, 33-39 [in Ukrainian].

Bromlei, U. (1971). K kharakteristike poniatiia «etnos» [To the characteristics of the concept of «ethnos»]. Rasy $i$ narody - Races and Nations, 1, 26-27 [in Russian].

Vodak, R. (2006). Vzaimosviaz «diskurs - obshchestvo»: kognitivnyi podkhod k kriticheskomu diskurs-analizu [The relationship «discourse society»: cognitive approach to critical discourse analysis]. Sovremennaia politicheskaia lingvistika - Modern political linguistics. Yekaterinburg [in Russian].

Golovakha, Ye. I. (1989). Psikhologiia chelovecheskogo vzaimoponimaniia [The psychology of human understanding]. Kiev : Politizdat [in Russian].

Horbachova, O. V. (2012). Protydiia proiavam ksenofobii orhanamy vnutrishnikh sprav Ukrainy: sotsialno-tekhnolohichnyi aspekt [Counteracting the manifestations of xenophobia by the Interior Ministry of Ukraine: the socio-technological aspect]. Extended abstract of candidate's thesis. Kharkiv [in Ukrainian].

Gurina, O. D. (2016). Ksenofobskiie ustanovki i lichnostnyie osobennosti podrostkov s deviantnym povedeniiem [Xenophobic attitudes and personality traits of adolescents with deviant behavior]. Psikhologiia i pravo - Psychology and Law, 1, 39-57 [in Russian].

Dubov, I. G. (1992). Vospriiatiie lichnosti politicheskoho deiatelia [Perception of the personality of a politician]. Psikhologicheskii zhurnal Psychological Journal, 6, 24-26 [in Russian].

Kroz, M. V. (2005). Sotsialno-psykholohichni ta pravovi aspekty ksenofobii [Socio-psychological and legal aspects of xenophobia]. Moskva [in Ukrainian].

(C) Nazarevych Victoriia

DOI (article): https://doi.org/10.32626/2227-6246.2020-47.159-178 
Malantseva, O. D. (2012). Sovremennyie napravleniia issledovaniia ksenofobii sredi podrostkov [Current trends in xenophobia among adolescents]. Sovremennaia zarubezhnaia psikhologiia - Modern foreign psychology, 3, 14-25 [in Russian].

Muraviov, A. (2004). Ksenofobiia: ot instinkta k ideie [Xenophobia: from instinct to idea]. Otechestvennyie zapiski - Domestic notes, 4 (19), 279-287 [in Russian].

Olport, G. (2002). Osnovnyie polozheniia psikhologii lichnosti. Stanovleniie lichnosti [Basic principles of personality psychology. Formation of personality]. Moskva : Smysl [in Russian].

Orban-Lembryck, L. (2007). Do pytannia pro mizhhrupovi konflikty i uperedzhennia [On the issue of intergroup conflicts and prejudice]. Sotsialna psykholohiia - Social Psychology, 3, 22-26 [in Ukrainian].

Pronyk, O. Yu. (2012). Systema subiektiv protydii ksenofobii [The system of subjects of xenophobia counteraction]. Pravo $i$ suspilstvo - Law \& Society, 1, 212-215 [in Ukrainian].

Skulkina, Ye. N. (2015). Individualno-psikhologicheskiie determinanty formirovaniia sotsialnykh ustanovok ksenofobii u podrostkov [Individual-psychological determinants of the formation of social attitudes of xenophobia in adolescents]. Psikhopedagogika $v$ pravookhranitelnykh organakh - Psychopedagogy in Law Enforcement, 60, 58-60 [in Russian].

Soldatova, G. W. (2003). Prakticheskaia psikhologiia tolerantnosti, ili kak sdelat tak, chtoby zazvuchali luchshiie struny chelovecheskoi dushi [Practical psychology of tolerance, or how to make the best strings of the human soul sound]. Vek tolerantnosti: nauchno-publitsisticheskii vestnik - The Age of Tolerance: The Journal of Science and Technology, 6, 16-19 [in Russian].

Trofimova, Ye. L. (2009). Osobennosti potentsialov mezhetnicheskoi konfliktnosti v yunosheskom vozraste i ikh korrektsiia [Features of potentials of interethnic conflict in adolescence and their correction]. Extended abstract of candidate's thesis. Moskva : MGPPU [in Russian].

Schaefer, B. (2004). Vospriiatiie chuzhogo kak faktor vozniknoveniia ambivalentnykh chuvstv [Perception of others as a factor in the ambivalent feelings emergence]. Psikhologiia - Psychology, 1, 24-51 [in Russian].

Schьtz, A. (2003). Smyslovaia struktura povsednevnogo mira [The semantic structure of the everyday world]. Moskva [in Russian].

Bernstein, M. J., Young, S. G., Brown, C. M., Sacco, D. F., \& Claypool, H. (2008). Adaptive responses to social exclusion: Social rejection im-

(C) Nazarevych Victoriia

DOI (article): https://doi.org/10.32626/2227-6246.2020-47.159-178 
proves detection of real and fake smiles. Psychological Science, 19, 981-983.

Blackhart, G. C., Nelson, B. C., Knowles, M. L., \& Baumeister, R. F. (2009). Rejection elicits emotional reactions but neither causes immediate distress nor lowers self-esteem: A meta-analytic review of 192 studies on social exclusion. Personality and Social Psychology Review, 13, 269-309.

Leary, M. R., \& MacDonald, G. (2003). Individual differences in selfesteem: A review and theoretical integration. Handbook of self and identity. New York : Guilford Press.

Williams, K. (2001). Ostracism: The Power of Silence. New York : Guilford Press.

\section{Назаревич Вікторія. Остракізм як прояв ксенофобії}

\section{АНОТАЦІЯ}

Метою статmі є особливості поняття соціальної ізоляції як прояву ксенофобії, які через власні характерологічні особливості містять у собі більшу загрозу суспільству, ніж відкрита агресія.

здійснено спробу методами синтезу зробити аналіз емоційної, когнітивної та поведінкової структур особистості, що впливають на особливості перебігу процесів остракізації. До пізнавальної форми належать самовідчуття, самоспостереження, уявлення про себе, самоаналіз, самокритика й інші ознаки деструктивного образу "Я» в ситуації соціальної ізоляції; когнітивний компонент характеризується наявністю ірраціональних конструктів особистості; емоційний - явищами самопочуття, самолюбства, гордості, які також піддаються впливу соціального вигнання чи ігнорування як найпоширеніших форм остракізації в сочіальному просторі.

Проаналізовано психологічні характеристики осіб, які піддаються явищу соціального неприйняття. Висвітлено основні наукові погляди на проблему остракізму, його роль в утворенні ксенофобних тенденцій, емоційних реакцій і станів, що переживає остракізатор, а також роль психологічних захисних механізмів, почуття страху як базової емоції неприйняття «чужих» індивідів.

За результатами дослідження вказано на взаємозалежність соціально-психологічних чинників середовища і формування тенденцій особистісного неприйняття.

C) Nazarevych Victoriia

DOI (article): https://doi.org/10.32626/2227-6246.2020-47.159-178 
Зроблено висновки в системі розгляду поняття остракізму як ксенофобічного прояву, що на глибинному когнітивно-емоційному рівні впливає на перебіг становлення особистості.

Подальший розгляд порушеної проблеми вбачаємо в більш розгорнутому вивченні основних критеріїв ксенофобних форм та остракізованих реакцій, що виникають при загрозі приналежності, передбачуваної девальвачії та відмови у взаєминах, а також у дослідженні взаємозалежності кількості відкритої агресії й остракізованих тенденцій у контексті ксенофобних проявів суспільства.

Ключові слова: остракізм, остракізатор, сочіальна ізоляція, інтолерантність, ксенофобія, емоційні стани, прийняття, захисні механізми.

\section{Назаревич Виктория. Остракизм как проявление ксенофобии}

\section{АНОТАЦИЯ}

Целью статьи являются особенности понятия социальной изоляции как проявления ксенофобии, которые через собственные характерологические особенности включают в себя большую угрозу обществу, чем открытая агрессия.

Предпринята попытка методами синтеза совершить анализ эмоциональной, когнитивной и поведенческой структур личности, влияющей на особенности протекания процессов остракизации. К познавательной форме принадлежат самоомущение, самонаблюдение, представление о себе, самоанализ, самокритика и другие признаки деструктивного образа "Я» в ситуации социальной изоляции; когнитивный компонент характеризуется наличием иррациональных конструктов личности; эмоциональный - явлениями самочувствия, самолюбия, гордости, которые также подвергаются воздействию социального изгнания или игнорирования как наиболее распространенных форм остракизации в социальном пространстве.

Проанализированы психологические характеристики лии, подвергающихся явлению социального неприятия. Освещены основные научные взгляды на проблему остракизма, его роль в образовании ксенофобских тенденций, эмоциональных реакций и состояний, которые переживает остракизатор, а также роль психологических защитных механизмов, чувства страха как базовой эмоции неприятия «чужих» индивидов.

(C) Nazarevych Victoriia

DOI (article): https://doi.org/10.32626/2227-6246.2020-47.159-178 
DOI: https://doi.org/10.32626/2227-6246.2020-47

По результатам исследования указано на взаимозависимость социально-психологических факторов среды и фрормирования тенденций личностного неприятия.

Сделаны выводы в системе рассмотрения понятия остракизма как ксенофобических проявлений, которые на глубинном когнитивно-эмоциональном уровне влияют на ход становления личности.

Дальнейшее рассмотрение этой проблемы видим в более развернутом изучении основных критериев ксенофобских форм и остракизированных реакций, возникающих при угрозе принадлежности, предполагаемой девальвации и отказа в отношениях, а также в исследовании взаимозависимости количества открытой агрессии и остракизированных тенденций в контексте ксенофобских проявлений общества.

Ключевые слова: остракизм, остракизатор, социальная изоляция, интолерантность, ксенофобия, эмоциональные состояния, принятие, защитные механизмы.

Original manuscript received November 28, 2019 Revised manuscript accepted February 10, 2020 